\title{
A LAKÓKÖRNYEZET MINŐSÉGÉNEK SZEREPE A FŐVÁROS MIGRÁCIÓS FOLYAMATAIBAN, AZ 1990-ES ÉVEKBEN
}

(Bevezetés a lakókörnyezeti lefelé és felfelé vándorlás elméletébe)

\author{
(The Influence of Quality of the Urban Environment on the \\ Migration Processes in Budapest in the 1990s)
}

\section{FÖLDI ZSUZSA}

\section{Bevezetés}

Vitathatatlan tény, hogy a rendszerváltást követöen mind a szociológia tudománya által vizsgált társadalmi (vertikális) mobilitás, mind pedig az ettől nagyban függö, a földrajz hatáskörébe tartozó térbeli (horizontális) mobilitás terén látványos, csak részben elöre jelezhető változások következtek be. A térbeli mobilitás irányát, távolságát, intenzitását érintő átalakulások a fỏvárost, mint a hatvanas és hetvenes években kiemelt vándorlási centrumot érzékenyen érintették: a nyolcvanas években megindulni látszó szuburbanizációs folyamatok a kilencvenes években uralkodó tendenciává váltak.

A fővárosi népesség térbeli mobilitásának intenzitásában, annak térbeli paramétereiben (irány, távolság) beállt változást, a fơvároson belüli migrációs centrumok és perifériák átszerveződését föként a jövedelmi polarizációból származó társadalmi átstrukturálódásnak, az új társadalmi rend és piaci viszonyok érték- és térszervező tevékenységének köszönhetjük. Az ủj értékrend, az újonnan szerveződő társadalmi érdek és jövedelmi csoportok lépésről lépésre formálják át a fővárost küllemében és tartalmában, ennek indirekt következményeként átszervezik a budapesti lakosság élet- és lakókörülményeit, és ezzel együtt területi átszervezödést is indukálnak.

\section{A lakókörnyezet mint a vizsgálat tárgya}

A területi átszervezödés alapfeltétele a vándorlás, ami alkalmazkodási, igazodási folyamat (Kok 1997). Jelen tanulmányban ezen alkalmazkodási folyamat lakókörnyezeti aspektusára kívánunk rávilágítani makro-, de elsősorban mikrovizsgálati szinten.

A térbeli mobilitás föbb tényezői közül sokkal inkább az irány, mint a távolság vizsgálatunk tárgya, amennyiben csak a fövároson belüli ill. az agglomerációba való kifelé vándorlás bizonyos környezeti tényezöit vettük figyelembe.

Fontos a lakókörnyezetnek mint tanulmányunk egyik alapfogalmának definiálása, majd minőségi szerepe helyének meghatározása a vándorlás mikro- és makroszintü vizsgálatában. 
A lakókörnyezet pontos fogalmi lehatárolásához segítséget nyújt Perényi Imre (1975) lakókörzetre vonatkozó definíciója, mivel bizonyos eltérések mellett számos hasonlóság is felfedezhetó az általunk kutatási alapegységként elképzelt lakókörnyezet fogalmával összevetve.

„A város lakóterületének alapfokú egysége a lakókörzet, amely kisebb kiszolgálási hatósugarú közintézményekkel rendelkezik, határozott lakóközösséget képez, ugyanakkor térbeli rendszert, egyưuttest alkot, amely több lakó- és középülettömbből, közhasználatú zöldterületböl, utak és terek rendszeréből áll." (Perényi 1975)

Vizsgálatunkban a lakókörnyezet az építész megközelítésével ellentétben kevésbé közigazgatási, intézményi, mint inkább társadalmi ill. a megélt környezeti feltételeket helyezi elötérbe és azok viszonylagos homogenitását hangsúlyozza, hiszen csak ebben a formában válhatnak lehatárolhatóvá és térben ábrázolhatóvá. Ezzel együtt is nehézségekbe ütközik a kutatási alapegységek lehatárolása, mivel a makroszintü vizsgálatokhoz szükséges alapadatok közigazgatási egységenként vannak rendszerezve. Kérdöíves vizsgálatunkból kiderült, hogy maguk az egyének is szívesebben gondolkodnak pl. kerületekben, amikor a lakókörnyezet minőségével kapcsolatos kérdésekkel szembesülnek.

A lakókörnyezet minöségét nem csupán a közterületek, középületek, lakóépületek állapota, az utcák, terek tisztasága jelenti, hanem a levegö- és zajszennyezés mértéke, valamint a mindezeket részben befolyásoló társadalmi összetétel és a közbiztonság is.

A vándorló, letelepedỏ személy szempontjảból a lakókörnyezet minősége mint migrációt befolyásoló tényező a nyolcvanas, még inkább a kilencvenes években kerülhetett elötérbe, mivel a korábbi időszakban az államnak túlzott szabályozó szerepe volt.

Általában jellemző, hogy az elmúlt időszakban megnövekedett a lakosság környezettudata és a környezettel szembeni felelösségérzete a nyugati életmód és igényesség követendő példaként való megjelenésével párhuzamosan. Kialakulóban van egy olyan társadalmi réteg, amelynél a lakókörnyezet minőségével szembeni igényességhez anyagi jólét is társul.

A rendszerváltást megelőző időszakból nem állnak rendelkezésre kérdőíves felmérésböl származó, migrációs döntéshozatalt befolyásoló tényezőkről szóló elemzések, ennélfogva nem állíthatjuk határozottan, hogy a lakókörnyezettel szembeni igények egyáltalán nem jutottak érvényre. Manapság a korábban szabályozott lakáspiac helyett a korlátozott pénzforrások szabnak határt a lakókörnyezeti igények kielégítésének.

\section{A lakókörnyezet helye a migráció mikro- és makroszintü vizsgálatában}

A lakókörnyezet minősége a migráció mikro- és makroszintú analízisében is helyet kap. Magát a migrációs folyamatot csak a kettỏ együttes vizsgálatával érdemes kutatni.

A makroszintủ vizsgálatok a lakóhelyi mobilitást, a mozgás különféle paramétereit a kibocsátó és migrációs célterületek társadalmi, gazdasági jellegzetességeinek, 
az épített és természetes környezet mérhetö jellemzőinek összehasonlításával magyarázzák. Ezzel szemben a mikroszintủ vizsgálat a vándorló döntéshozatali folyamatára helyezi a hangsúlyt (Cadwallader 1989).

A két elemzési szint összetalálkozik, amennyiben megnézzük, hogy a makroszinten jelentkező mérhető jellemzök információtartalma hogyan épül be és szubjektivizálódik az egyén migrációs döntéshozatali folyamatában. Az egyén oldaláról a jövedelem, életvitel, családi háttér mellett jelentkeznek a lakókörnyezettel szembeni elvárások, amelyek együttesen jelennek meg a lakásigényekben a keresleti oldalon. A makroszintú információ a kínálati oldalon jelentkezik, amennyiben a lakáspiacon felkínált házak ill. lakások társadalmi, gazdasági, környezeti jellemzöit értékeli a potenciális migráló (Kovács 1989).

A különféle tényezők nem egyformán fontosak a vándorlási döntéseknél, illetve nem fejeződnek (fejeződhetnek) ki egyforma erősséggel magában a migrációs tevékenységben (Halfacree-Boyle 1993).

Az egyén vándorlási életútját a számos, azzal párhuzamosan zajló egyéb életpályák (karrier, család stb.) nagyban befolyásolják. Egy másik jövedelmi státuszba vagy korcsoportba való átlépés radikálisan átrendezheti az egyén értékrendjét, életvitelét korábban meghatározó prioritásokat, amelyek a vándorlási döntéseknél jól követhetők (Mulder 1993).

A jövedelmi kohorszváltás pl. elötérbe helyezheti a lakókörnyezet minőségét mint a döntést befolyásoló alaptényezöt, illetve amennyiben ez negatív irányú, háttérbe is szoríthatja azt. Ez annyit jelent, hogy Magyarországon a rendszerváltást követő időszak megváltozott viszonyai által indukált társadalmi mobilitás részeként megjelenő lefelé és felfelé vándorlás lakókörnyezeti szempontból analóg változásokat gerjesztett. A kohorszváltás gyakran indukál lakóhelyváltoztatást. A lakóhely megváltoztatása a lakókörnyezet bizonyos elemeiben is feltétlen változást jelent, ami a korábbi lakóhelyhez képest lehet pozitív vagy negatív irányú.

Olyan mechanizmusok indultak be és erősödtek fel a kilencvenes évek Budapestjében, amelyek bizonyos társadalmi rétegeknek jobb minőségủ lakókörnyezetbe való letelepedését tették lehetővé, míg másokat a korábbinál jóval rosszabb lakókörnyezetbe kényszerítettek.

Elképzelésünk szerint a szociológiában használatos társadalmi mobilitás lefelé és felfelé irányultsági elméletére alapozva beszélhetünk lakókörnyezeti lefelé és felfelé vándorlásról is.

Eszerint, ha a migráló egyén a korábbi lakóhelyéhez képest rosszabb minőségủ lakókörnyezetbe kényszerül (vagy azt választja), lakókörnyezeti szempontból lefelé vándorlást végez; amennyiben az egyén lakókörnyezetének minösége a vándorlással pozitív irányban változik, lakókörnyezeti felfelé vándorlásról beszélhetünk.

A lakókörnyezet minősége mindenkori függvénye az ott élỏ népesség társadalmi összetételének, a használat intenzitásának, funkcióinak, bizonyos - mélyen a város történelmében gyökerező - hagyományoknak és nem utolsó sorban az önkormányzatok fejlesztési politikájának. A társadalmi polarizálódás és az ennek következté- 
ben jelentkező szegregálódás együtt jár a lakókörnyezeti övezetek minőségében felerösödő differenciálódással.

Mivel a különféle minőségü lakóterületek egyes jellemzöire vonatkozóan csak részlegesen állnak rendelkezésre adatok (lakásárak, zöldterületek eloszlása, szegregációs térképek) és ezek is inkább csak makroszintü vizsgálatokra alkalmasak, a lakỏhely környezeti elemeinek migrációban játszott szerepét vizsgálva kérdöíves felmérésbe kezdtünk.

\section{A kérdöives felmérés eredményei}

A Xántus János Idegenforgalmi Középiskolában lehetőség nyílt egy jövedelmi és társadalmi helyzeténél fogva magasabb státuszú, ennél fogva viszonylag mobilabb réteg felmérésére olymódon, hogy a tanulókkal a 20 évesnél idősebb családtagokhoz igyekeztünk eljuttatni a felméréshez készített kérdéssort. A kérdőív annak tanulmányozására született, hogy milyen kapcsolat van Budapest lakosságának belső mobilitása és a városi környezet állapota között az adott társadalmi csoport esetén.

A szétosztott kérdöívek (500 db) mintegy 25\%-a nem került vissza, és kb. 15\%-a hiányos vagy értékelhetetlen volt. Az adatfeldolgozásnál tehát 341 értékelhető kérdöív állt rendelkezésünkre. Az anonim ív tartalmazott mikro- és makroanalizisre alkalmas kérdéseket is.

A leadott válaszok 23\%-a a 20-30 éves, 35\%-a a 31-40 éves, $65 \%$-a a $41-50$ éves, míg $16 \%$-a az 50 év feletti korosztályból került ki.

A 41-50 év közötti korosztály kiemelt számaránya a középiskolások szüleinek korcsoportját mutatja. A kérdőív első szakaszában a migrációs irányt és távolságot feltárandó rákérdeztünk a jelenlegi és a jelenlegit közvetlen megelöző lakcímre és a legutóbbi lakóhelyváltoztatás idöpontjára.

Az utóbbi adatokból kiderült, hogy a korcsoportok sajátosságait figyelembe véve az 1990 óta eltelt időben végzett vándorlások tekintetében a 20-30 év közötti korosztály a vezető (itt az összes megkérdezett 77\%-a költözött), míg a legkisebb arány a negyedik korcsoportnál jelentkezett $22 \%$-kal. A vizsgálat tanulsága szerint a korcsoportok közötti ugrással csökkent a migrációs aktivitás a megkérdezettek körében. Az összes megkérdezett 56\%-a végzett lakóhelyváltoztatást az elmúlt 10 éven belül, ami egészében véve igen magas arány, bár amint a fentiekben jeleztük, komoly korcsoportok szerinti eltérések mutatkoznak.

A lakókörnyezet migrációban játszott szerepének vizsgálatához a legutóbbi lakóhely- változtatás okainak elemzése adott jelentős segítséget. A megkérdezettek választhattak a felsorolt öt migrációs ok közül, illetve maguk is megjelölhettek egyéb kategória címen másokat. Vándorlási okként több kategória is megjelölhető volt, de kértük, hogy jelezzék a legmeghatározóbbat. Az öt kategória egyike a kellemes lakókörnyezet iránti igény volt. Emellett igyekeztünk olyan okokat megjelölni, amelyek különös jelentőséget nyernek az egyén egyes életszakaszaiban, és vándorlást indukálhatnak (család mérete, egyéb családi okok, mint pl. válás, házasság- 
kötés, megözvegyülés, munkahelytől való nagy távolság, a lakás magas fenntartási költségei).

Korcsoportonként jellemzöen kaptak hangsúlyt az egyes tényezők, így az elsö korcsoportnál az egyéb családi ok (házasság, függetlenedés, válás), a második és harmadik csoport esetén a család mérete, míg a negyediknél újra az egyéb családi ok (özvegyülés, gyerekek „kirepülése”) vált az elsödleges migrációs okká a vizsgált mintában.

A lakókörnyezettel szembeni igények vándorláson keresztuli kielégítése jelentöséget nyer minden korosztályban, de szembeötlöen eltérö mértékben. A lakókörnyezettel szembeni elvárások egyéb migrációs okokhoz viszonyított aránya mellett arra is igyekeztünk választ kapni, hogy mely korosztálynál jelentkezik ez a tényezö legnagyobb arányban mint egyedüli vándorlási indok.

A legfiatalabb és legidősebb csoportnál a lakókömyezet minősége nem több, mint 27\%-ot képvisel a migrációs tényezök körében, és csak mintegy 5-6\%-ban jelentkezik egyedüli vándorlási okként. A 31-40 és a 41-50 éveseknél a megkérdezettek $40 \%$-ánál válik valós mozgósító elemmé a környezet minősége. Az egyedüli, viszont szembeötlö különbség, hogy egyedüli migrációs okként a harmadik korosztálynál már 20\%-ot képvisel a lakókörnyezettel szembeni igényeknek a vándorláson keresztül történö érvényre juttatása (a második csoportnál ez megmarad 6\%-nál).

Érdemes megfigyelni, hogy a környezet minösége miatt migrálók jelenleg milyen lakóháztípusokban élnek, ugyanis markáns eltérés jelentkezik a csupán ezen tényező miatt lakóhelyet változtatók, illetve az ezt mellékes okként szerepeltetök lakóhelye között.

Nem törvényszerü, hogy egy panellakás vagy egy századfordulón épült bérlakás lakókömyezete elfogadhatatlanul rossz (gondoljunk csak a Római-parton a nyolcvanas években felépült lakótelepre), viszont a felmérés tanulsága szerint az emberek számára a kellemes lakókörnyezet leginkább a családi illetve társasházi beépítettségü lakókörzetet jelenti. A kérdöivek elemzése során azt találtuk, hogy a csak a lakókörnyezet miatt migrálók 64\%-a családi vagy társasházas, míg fennmaradó 36\%-uk a panel- vagy bérlakásos megoldást választotta. Ez az arány erösen megváltozik annál a csoportnál, ahol a környezet csak másodlagos vagy harmadlagos okként jelentkezett. Itt a családi és társasházi forma csak 47\%-ot, míg a panelés bérlakásos forma 53\%-ot képvisel. Természetesen ezekben az esetekben sok egyéb, a migrációs célterületet befolyásoló tényező is jelentkezett az egyes vándorlók döntéshozatalában, így annak magában kellett foglalnia bizonyos kompromisszumokat a lakókömyezet minöségét illetően.

Tovább vizsgálva ezen két csoport migrációhoz való viszonyát, azt elemezzük, hogy mennyiben elégedettek ezek az egyének jelenlegi lakhelyükkel, és milyen arányban jelentkezik a továbbköltözés szándéka a közeljövőre vonatkozóan.

Könnyelmüség volna bárki részérỏl is azt állítani, hogy megtalálta migrációs életútja során azt a helyet, ahol élete végéig lakni szándékozik. Minden egyén vándorlási életútjával párhuzamosan folyó egyéb karrierjében elöfordulhatnak olyan válto- 
zások, amelyek vándorlási szándékot indukálhatnak az egyén bizonyos életszakaszaiban.

A felmérés alapján úgy tünik, hogy amennyiben az egyén és a vele költözỏ család olyan szituációba kerül (társadalmi státusz, jövedelmi csoport), amikor a lakókörnyezet minösége válhat az elsődleges szelektálási tényezỏvé, úgy érzik, elérkeztek vándorlási életútjuk végsỏ vagy legalábbis hosszabb időre tartósnak vélt állomásához.

A vizsgált csoportok közül a csupán a környezet miatt vándorlóknál a továbbköltözési szándék kevesebb, mint 10\%-os, míg a környezetet csak másodlagos migrációs okként megjelölöknél ez közel 40\%-os.

A kérdőives felmérés további feldolgozásánál érdemesnek tartottuk megvizsgálni az összes korcsoport továbbköltözési szándékának arányát, irányát illetve szándékolt célterületét. A korcsoportok között jellegzetesen a legnagyobb arányú továbbköltözési szándék (mintegy 40\%) a legfiatalabb korosztálynál jelentkezett. Ezen belül is a máshol letelepedni vágyók kicsivel kevesebb, mint fele az agglomerációt választaná legközelebbi vándorlási céljául. Ennek több oka is lehet, de valószínủsíthetö, hogy a kellemesebb lakókörnyezet iránti igény szándék szintjén már ebben a korcsoportban is megjelenik. Természetesen ennek lehet sok egyéb oka is, pl. a kedvezöbb, vállalkozásbarát önkormányzatok adókedvezményei illetve a kényszervándorlás. Amennyiben ez az igény valóban a kellemesebb lakókörnyezet iránti vágy megnyilvánulása, kérdés, hogy az egzisztenciájukat jellegzetesen ebben a korban magalapozó korosztály mennyiben jut el olyan szintre a családalapítás idószakában társadalmi státus illetve jövedelemszint tekintetében, hogy ezt megengedhesse magának.

A 31-40 év közötti válaszadóknál a továbbköltözési szándék valamivel alacsonyabb szinten áll, de az agglomeráció mint célterület felerösödik és meghaladja az $50 \%$-ot. (Ez is mutatja, hogy az előző csoportnál megjelenő igény csak kis mértékben realizálódik a 40 év körüli időszakot megelözöen.)

A harmadik korosztálynál (41-50 évesek) közel 20\%-ra csökkent a vándorlási szándék, és ezen belül a Budapestet elhagyni vágyók aránya radikálisan lecsökken (valószínüleg azért, mert már vagy az agglomerációban élnek, vagy pedig egyéb, városon belüli lakókörnyezetben kívánják megtalálni az igényeiknek megfelelő lakóhelyet).

Érdekes volt megfigyelni, hogy az 50 év felettieket magában foglaló csoportnál újból felerösödik az elvándorlási szándék (majdnem a 31-40 évesek szintjére emelkedve). A vidéki lakókörnyezetbe való kivándorlás igénye viszont itt már jóval kisebb, az idős korral járó nehézségek miatt.

Ha a költözést tervezök jelenlegi lakóhelyére koncentrálunk, igazolva érezhetjük azt a korábbi észrevételt, hogy lakókörnyezeti szempontból a panel- és bérlakásos forma jelenleg nem tartozik a legvonzóbbak közé a megkérdezettek körében Budapesten. Korcsoportoktól függően változóan 60-75\%-ban állapitható meg azok aránya, akik panel- vagy bérlakásból kívánnak elköltözni. 
A potenciális migrációs célterületek feltárására vonatkozóan feltett kérdésre, miszerint: „Valós anyagi lehetőségeit figyelembe véve mely kerületbe vagy városkörnyéki településre költözne a legszívesebben és miért?" - a következő válaszok érkeztek:

A megkérdezettek harmada jelölte meg az agglomerációs gyürüt mint potenciális letelepedési célpontot. Legfontosabb indokként a kellemes lakókörnyezetet és a fövárosi munkahelyek illetve iskolák viszonylag gyors elérhetőségét említették. A főváros kerületei közül a XIV., III. és a XI. kerületek összesen hasonló arányban szerepelnek, mint a városon kívül esö települések. Mindhárom kerület esetében a még elérhetö legmagasabb színvonalú lakókörülményeket, a könnyen elérhetö zöldterületet illetve a városközpont gyors megközelíthetőségét jelölték meg vonzó tényezőként.

Érdekes azonban, hogy a „Hová költözne, amennyiben semmiféle dolog nem gátolná szabad választásában?” kérdésre adott válaszok alapján összeállított „álomlistán" vezetö II. és XII. kerületek a valós anyagi lehetöségek figyelembevételével készített rangsorolásban nagyon hátracsúsznak (a megkérdezettek 4-5\%-a gondolja úgy, hogy ezek a kerületek potenciális céljai lehetnek következő költözésüknek). Habár a felmért társadalmi csoport nem a lecsúszott rétegeket képviseli, belátható, hogy ez a terület csak a kiemelten magas jövedelemmel rendelkező társadalmi csoportok számára hozzáférhető, még a megkérdezett emberek elképzelése szerint is. Ránézve Budapest lakásárainak 1988-as térképére (Kovács 1989) vagy egyszerủen csak egy hirdetési újságot böngészve világossá válik, hogy ezek a kerületek szinte elérhetetlenek a közemberek számára, amikor valós migrációs célterületeket keresnek.

A megkérdezettek körében potenciális célkerületek még az I., a IV., a XIII. és a XV. kerületek, bár egyes esetekben a munkahely gyors elérhetósége miatt a belsö kerületek is előtérbe kerültek.

Nem kerültek nagy számban megjelölésre, illetve lehetőségként fel sem merültek a klasszikus bérlakás övezet kerületei illetve a hatvanas-hetvenes évek nagy lakótelepeit magukban foglaló külső kerületek sem. Természetesen ezek a valós lehetöségeken nyugvó preferenciák teljesen más képet mutatnának egy alacsonyabb társadalmi státusszal bíró csoport vizsgálata esetén. Valószínü, hogy előtérbe helyeződnének azok a lakóterületek, amelyek ennél a csoportnál meg sem említődtek. Így a társadalmi, jövedelmi kohorszok közt lefelé haladva a környezeti igényesség mint migrációs tényezỏ egyre kevésbé jelentkezne, hiszen sokkal alapvetőbb igények kielégítése is akadályokba uitközik (gondoljunk csak a Józsefvárosban uralkodó, jól ismert és feltárt körülményekre).

A válaszadók arra a kérdésre, hogy mely kerületben laknának a legkevésbé szívesen, a belső lakóövön kívül a hagyományos ipari kerületeket jelölték meg. A negatív csúcsot a VIII. kerület érte el, ahol a zsúfoltságon, az erőteljes zaj- és levegöszennyezettségen kívül föként a társadalmi összetételt és az ezzel nagyban összefuiggő közbiztonságot jelölték meg indokként.

A főváros egyes területegységei nem jelennek meg markánsan a válaszadók „mental map”-jén, így azt mondhatjuk, hogy ezek a területek a semleges vagy 
egyéni élményeken alapuló változó megítélésủ migrációs célterületeknek nevezhetők. Például a Budapest déli részén fekvő kerületek (XX., XXI., XXII. kerület) szinte semmiféle formában nem kerülnek említésre a kérdőívekben (sem pozitív, sem pedig negatív asszociációval). Érdekes módon ezek azok a kerületek, ahol a nyolcvanas évek végén alacsony volt a társadalom lakóhelymobilitása (Kovács 1989).

A jelenlegi lakóhely egyes lakókörnyezeti elemeinek szubjektív értékelése kapcsán a megkérdezett személyek egy 1-töl 5 pontig terjedő skálán minősíthették lakókörnyezetük állapotát és egyéb, a lakóhelyükkel összefüggő paramétereket ill. az azokkal való elégedettséget. Ha nem vennénk figyelembe Budapest sajátos topográfiai jegyeit, logikus volna pl. korrelációt keresni a levegő minősége és a városközpont gyors elérhetősége között.

Egy „ideális” város esetén a központ elérhetőségével való maximális elégedettség a legrosszabb értéket vonná maga után a levegö minösítésében. A föváros esetében ilyen összefüggés nem volt kimutatható. Ennek a már említett sajátos domborzati viszonyok és a viszonylagosan jó közlekedési adottságok a valószínúsíthető okai.

Ugyanezen értékelő skálát használtuk fel a lakókörnyezet minöségét befolyásoló fontos tényezö, a társadalmi összetétel területi vizsgálatához. Arra voltunk kiváncsiak, hogy a tudományos alapon, bonyolult számítási módszerekkel összeállított társadalmi szegregációs térképek (Rédei 1994) mutatnak-e hasonlóságot a társadalmi összetétellel való elégedettség illetve elégedetlenség szubjektív véleményekre alapozott, általunk készített térképével. Csak azokat a véleményeket lokalizáltuk, amelyek maximális elégedettséget vagy teljes elégedetlenséget mutattak. A térképek szembeötlö hasonlóságot mutattak, amennyiben a társadalmi összetétellel maximálisan elégedettek a pozitív szegregációs térkép kiemelten magas státuszú körzeteire estek, míg a teljes elégedetlenséget jelentő lakóhelyek a negatív szegregációs térképpel mutattak hasonló, de nem annyira markáns egybeesést. Ez valószínüleg azért van, mert a legalacsonyabb státuszú lakóterületekröl származó személyek nem szerepeltek a mintavételi csoportban.

Ebböl is leszürhető, hogy a tanulmány elején szereplő állítás, miszerint a mikroés makroszintü vizsgálatok csak egymást alátámasztva igazán relevánsak, nem csak a migrációs kutatásokra igaz.

Végezetül szeretnénk visszatérni a lakókörnyezeti lefelé- és felfelé vándorlás elméletéhez. A kérdőives felmérés adatai csak részben adtak lehetőséget az elmélet valós tartalmának empirikus alátámasztására, ezért csak néhány jellegzetes példával kívánjuk ennek gyakorlati alkalmazhatóságát illusztrálni.

A kérdőives adatokat elemezve inkább a lakókörnyezeti felfelé mobilitásra találtunk példákat, a vizsgált minta korábban említett sajátosságai miatt. Jellegzetesen az „álomlista” élén álló II. és XII. kerületben az ott újonnan lakást vásárlók 60-66\%-a eredetileg is az adott kerületben élt. Igen kicsi azok aránya, akik valamilyen alacsonyabb státuszú kerületböl, vagy netalán a fövároson kívülröl egyenesen ezekbe a kerületekbe kerülnének lakókörnyezeti felfelé vándorlást végezve. 
A reális fővárosi célkerületek közül a III. és a XI. kerületekben már más a helyzet. Az elemzett kérdőivek alapján kiderült, hogy a kerületen belül vándorlók aránya alacsonyabb (40-45\%), nagyobb ,teret” hagyva az alacsonyabb státuszú kerületekböl történő felfelé migrálóknak. A III. kerület esetében kilencvenes években ủjonnan letelepedők $60 \%$-ának korábbi lakóhelye rosszabb minőségủ lakókörnyezet volt (nagyrészük a VII., IX., X. kerületből érkezett). Ezekben az esetekben egyértelmüen jelentkezik a lakókörnyezeti felfelé vándorlás. Sajnos a kérdőívekből nem derül ki, hogy milyen jellegủ változás tette lehetỏvé ezt a változtatást, de amennyiben figyelembe vesszük a lakásárakban való különbségeket, biztosra vehetjük, hogy a jövedelmi kohorszváltásnak is szerepe lehetett a változtatás lehetőségében.

A kevésbe népszerü vándorlási célterületek közül a VI. és a VII. kerületeknél az új lakóhely változtatók $60-70 \%$-a már eredetileg is ebben a lakóhelyi miliőben élt. Ahogyan azt már említettük, lakóhelyi lefelé mobilitásra csak egyes eseteket találtunk; ennek pontosabb vizsgálatához egy alacsonyabb, illetve romló státuszú társadalmi csoport kérdöíves felmérésére van szükség.

A tanulmány zárásaként hangsúlyozni kívánjuk, hogy a lakókörnyezet minőségének migrációban játszott szerepére vonatkozó konkrét kutatások még kezdeti stádiumban vannak. Magyarországon még általában nem, illetve igen szük csoportra jellemző, hogy a migrációs döntéseknél a jövedelemszint nem akadálya a lakókörnyezettel szembeni igények, vágyak vándorláson keresztül történő megvalósításának.

Remélhetöleg a piaci viszonyok megváltozásával és a jövedelemszintek fokozatos kiegyenlítődésével ez a tendencia pozitív értelemben fog változni, lehetőséget adva egyre szélesebb rétegek számára lakókörnyezeti igényeik megvalósítására.

\section{Irodalom}

Cadwallader, M. (1989) A conceptual framework for analysing migration behaviour in the developed world. - Progress in Human Geography. 13. 494-511. o.

Halfacree, K.H.-Boyle, P.J. (1993) The challenge facing migration research: the case for a biographical approach. - Progress in Human Geography. 3. 333-348. o.

Kok, J. (1997) Migration in Hungary and Poland before and after the transition. Budapest, EXEON Bt.

Kovács Z. (1989) A lakásmobilitás társadalomföldrajzi vizsgálatának leheöségei Budapest példáján. Földrajzi Értesitö. 1-2.93. o.

Mulder, C. (1993) Migration dynamics: a life course approach. Amsterdam, Thesis Publishers.

Perényi I. (1975) Városi környezet- városépítészet. Budapest, Akadémiai Kiadó.

Rédei M. (1994) Budapest szegregációs tanulmánya. Kézirat.

\section{THE INFLUENCE OF QUALITY OF THE URBAN ENVIRONMENT ON THE MIGRATION PROCESSES IN BUDAPEST IN THE 1990S}

\section{ZSUZSA FÖLDI}

Along with the political, economic, social changes, which have happened since 1989 the direction and the intensity of the main migrational flows have altered substantially. Among the main reasons of spatial migration the quality of the urban environment seems to have 
become decisive in certain age groups and social spheres. My research aimed at the discovery of these groups on the basis of questionnaires distributed among the students (parents, relatives) of a secondary school. On the basis of these I found that the group of people in which it has the most importance on is between the age of 41-50. It is obviously because of the fact that by this age people may reach the highest social position and the dissatisfaction with the quality of the surrounding area, may become the exclusive reason for leaving (provided that the social position change means bigger income). I also found that this group has no intention of further migration. The study focuses on the most favoured and refused areas of the capital city from the point of view of urban environment. 